\title{
L. O. Darkshevich (1858-1925) (150th anniversary)
}

\author{
Enver I. Bogdanov $\cdot$ Ravil Z. Mukhamedzyanov • \\ Alexey S. Sozinov $\cdot$ Joel A. Vilensky
}

Received: 30 January 2009/Accepted: 18 February 2009/Published online: 11 March 2009

(C) Springer-Verlag 2009

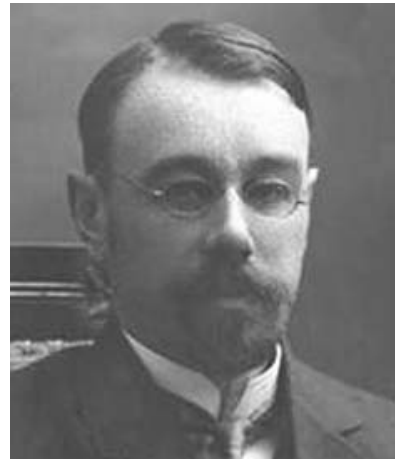

Livery Osipovich Darkshevich (sometimes spelled Darkschewitsch), neurologist and clinician-scientist of the latter half of nineteenth and early twentieth century, played a crucial role in developing Russian neurology during this transitional time in Russian history [1,9]. His name is not as well known as some of his contemporaries, such as S. S. Korsakov, A. Y. Kozhevnikov or V. M. Bekhterev, but he is especially remembered for his 1889 description of the

E. I. Bogdanov $\cdot$ R. Z. Mukhamedzyanov

Department of Neurology,

Kazan State Medical University, Kazan, Russia

A. S. Sozinov

Department of History of Medicine,

Kazan State Medical University, Kazan, Russia

J. A. Vilensky $(\square)$

Department of Anatomy and Cell Biology,

Indiana University School of Medicine,

2101 E. Coliseum Blvd., Fort Wayne, IN 46805, USA

e-mail: vilensk@ipfw.edu lateral interstitial nucleus of the midbrain, which since that time has been referred to as the nucleus of Darkshevich.

L. O. Darkshevich was born on July 17, 1858, over 150 years ago, into the family of a military doctor. In 1882 , Darkshevich graduated from the Medical Faculty of Moscow University. Between 1883 and 1887, he studied abroad at Meynert's laboratory in Vienna, Flechsig's laboratory in Leipzig, Westphal's clinic in Berlin, Goltz's clinic in Strasbourg and Charcot's clinic at the Salpêtrière hospital in Paris. During this training period, he published 11 papers in German and French journals including reports on the neurological manifestations and muscle disturbances in tabes dorsalis in collaboration with J. Dejerine. Additionally, he collaborated with Sigmund Freud [3, 4], discussing the brainstem connections of the VIIIth cranial nerve and erroneously concluding that the "vestibular nucleus of Deiters" was the third auditory nucleus. Darkshevich drew the illustrations for this work [4, 12].

In 1887, Darkshevich defended his thesis, "O provodnike svetogo razdrazenija s setcatoj obolocki glaza na glazodvigatel'nyj nerv" (The conduction of light stimulus from the retina to the oculomotor nucleus) under Dr. A. Y. Kozhevnikov in Moscow.

In 1889, he identified the nucleus of the posterior commissure (nucleus of Darkshevich) [5]. Modern studies have found that isolated lesions of this accessory oculomotor nucleus lead to vertical gaze palsy [2]. Subsequently, Darkshevich became an associate professor at Moscow University and a prominent member of the Moscow neurological school, which was founded by his mentor, Dr. A. Y. Kozhevnikov. In 1892, he became the director of the Department of Neurology at Kazan based on recommendations by Kozhevnikov and Bekhterev, who directed the Psychiatry department at Kazan Imperial University from 1885 until 1893. His appointment to this position marked 
the foundation of the Kazan school of neurology. During his tenure at Kazan, he developed the University neurological clinic and laboratory. After a few years, it included a separate out-patient department, a laboratory with superb microscopes, X-ray facilities, electrotherapy facilities, operating rooms and a museum. During this period, Darkshevich described the distribution of the posterior root fibers projecting to Clarke's column, the distribution of the fibres arising from Goll's and Burdach's nuclei as part of the restiform bodies, secondary degeneration of nerve fibres, and degeneration of the posterior columns secondary to damage of the cauda equina or other posterior roots, as in tabes dorsalis. In 1892, he published the first Russian case of ophthalmoplegic migraine as "recurrent oculomotor neuropathy," noting its vascular nature. He also demonstrated arthrogenic muscular atrophies, autonomic components in peripheral nervous system disorders and arthropathies in syringomyelia. As a teacher and academic neurologist, Darkshevich always tried to bridge the gap between anatomy and patients. Between 1904 and 1917, he published Course of Nervous Diseases, in three volumes, the first Russian textbook on neurological diseases [6]. The section on myology was reprinted in the well known German neurology text, Handbuch der Pathologischen Anatomie des Nervensystems in 1904 [7]. Darkshevich organized and became the first editor of the Kazan Medical Journal (Kazanskii Medicinskii Jurnal), which has been continually published since 1901. In 1905, Darkshevich became the chairman of the Kazan Society for Neurologists and Psychiatrists, which was founded in 1892 by V. M.Bekhterev. One of the operating rooms of Kazan University clinic was reserved for major brain surgery; the neurosurgeon Rasumovsky, after detailed discussions with Darkshevich, performed operations for epilepsy there by extirpating cortical centers following the technique of Horsley [10].

In 1917, Darkshevich became head of the Department of Neurological Disorders at the Medical Faculty of Moscow University and director of the Moscow Regional Clinical Institute, while also taking an active part in the organization and leadership of the third Moscow Medical Institute. Darkshevich became a medical consultant for Lenin in 1922 with other leading European neurologists (A. Strumpell, S. Henschen, V. M. Bekhterev, and G. I. Rossolimo). In that period, Darkshevich was one of the first
Russian physicians to study epidemic encephalitis. He preferred the term "encephalo-myelo-meningitis epidemica," and reported that sometimes the disease began with psychological symptoms [11]. He also published the brochure Apostle Paul as part of the series Brief Characteristics of the Figures from the Holy Bible Times. On the Problem of Hysteria in the History of Nations [8], concluding that Paul and his companions influenced masses of people by means of "suggestion". Darkshevich died in Moscow in March, 1925 from complications of cerebrovascular disease and uremia. He was buried at the famous Novodevichy cemetery in Moscow.

\section{References}

1. Amirov NKh, Bogdanov EI, Ismagilov MF, Mukhamedzyanov RZ, Sozinov AS et al (2007) The history of Kazan neurological school. J Hist Neurosci 16:110-122. doi:10.1080/09647040600659086

2. Clark JM, Albers GW (1995) Vertical gaze palsies from medial thalamic infarctions without midbrain involvement. Stroke 26:1467-1470

3. Darkshevich LO, Dejerine JJ (1885) Sur L'existence d'altérations dans certaines paralysis des muscles de l'oeil chez les tabétiques. CR Soc Biol 5

4. Darkschewitsch L, Freud S (1886) Ueber die Beziehung des Strickkoerpers zum Hinterstrang und Hinterstrangkern nebst Bemerkungen ueber zwei Felder der Oblongata. Neurol Zbl 5:121-129

5. Darkshevich LO (1889) Uber den oberen Kern des N. Oculomotorius. Arch Anatom Fysiol 1-2:107-116

6. Darkshevich LO (1904-1917) Course of nervous diseases (3 volumes). Br.Bashmakovy, Kazan 1:485 pp; 2:476 pp; 3:234 pp

7. Darkshevich LO (1904) Die pathologische Anatomie der Muskeln. In: Flatau E (ed) Handbuch der Pathologischen Anatomie des Nervensystems. Karger, Berlin, pp 1218-1270

8. Darkshevich LO (1923) Apostle Paul. Beglye characteristiki deyatelei vremen svyachennogo pisaniya. $\mathrm{K}$ voprosu ob isterii $\mathrm{v}$ istorii narodov, Kirchner, Berlin, 86pp

9. Popelyansky YaYu (1976) Professor Liveri Osipovich Darkshevich. Tatknigoisdat, Kazan, 214pp

10. Razumovsky VI (1913) Zur frage der trepanation bei corticaler epilepsie. Arch Klin Chir B 101, H 4, S 1075-1087

11. Vilensky JA, Mukhamedzyanov RZ, Gilman S (2008) Encephalitis lethargica in the Soviet Union. Eur Neurol 60:113-121. doi: $10.1159 / 000144080$

12. Wiest G, Baloh R (2002) Sigmund Freud and the VIIIth cranial nerve. Otol Neurotol 23:228-232. doi:10.1097/00129492200203000-00021 